\title{
SYNONYMIC NOTES ON LEPIDANTHRAX OSTEN SACKEN \\ AND REDESCRIPTION OF L. TINCTUS (THOMSON) \\ (DIPTERA, BOMBYLIIDAE, ANTHRACINAE)
}

\author{
Carlos José Einicker Lamas ${ }^{1}$ \\ Márcia Souto Couri ${ }^{1}$
}

\begin{abstract}
Based on the analysis of types, Lepidanthrax brachialis (Thomson, 1869 ) and $L$. quinquepunctatus (Thomson, 1869) are considered junior synonyms of L. tinctus (Thomson, 1869). Notes and illustrations of the type are presented. KEY WORDS. Diptera, Bombyliidae, Lepidanthrax, synonymic notes
\end{abstract}

OSTEN SACKEN (1886) erected the genus Lepidanthrax for two species previously included in Anthrax: L. disjunta (Wiedemann, 1830) and L. proboscidea (Loew, 1869) and a new species, L. angulus, and stated that Lepidanthrax is easily segregated from Anthrax, "not only by the general appearence and colouring, but by its long proboscis, the more distinct spinules on the front tibiae, and the venation."

Thomson (1869) described three new species in Anthrax: A. tinctus, A. brachialis, A. quinquepunctatus.

PAINTER \& PAINTER (1962) transferred A. quinquepunctatus to Lepidanthrax, and stated that "this species, together with brachialis (Thomson, 1869) and tinctus (Thomson, 1869) from the Galapagos Island, constitute a new group of species in Lepidanthrax, distinguished from the other species in genus by their characteristic wing pattern."

PAINTER \& PAINTER (1974) redescribed L. brachialis and L. tinctus, based on the examination of the types, and stated that L. tinctus is possibly the female of L. brachialis. They stressed that these two species together with $L$. quinquepunctatus constitute a group in Lepidanthrax.

Examining the types of $L$. brachialis (only three males are known), L. tinctus (only three females are known) and L. quinquepunctatus (one male and one female are known), it is concluded that all belong to the same species, which presents an evident sexual dimorphism in the color pattern of the wing. Based on page priority, L. tinctus should be the valid name.

Almost all the examined material has incomplete labels ("Ins. Gallop/Kinb."), but according to Dr. Bert Viklund, Swedish Museum of Natural History (in litt.) the specimens were collected in Galapagos Island in 11-20.V.1852 by the Swedish Eugenie-expedition in 1851-1853.

1) Museu Nacional, Universidade Federal do Rio de Janeiro. Quinta da Boa Vista, São Cristóvão, 20940-040 Rio de Janeiro, Rio de Janeiro, Brasil. CNPq fellow. 


\section{Lepidanthrax tinctus (Thomson, 1869)}

Anthrax tinctus Thomson, 1869:483. - Painter \& Painter, 1974: 116. - Evenhuis, 1983: 490.

Villa tincta; Hull, 1973: 373.

Lepidanthrax tinctus; Painter \& Painter, 1974: 116. -Painter et al., 1978: 36. - Evenhuis, 1983: 490.

Anthrax brachialis Thomson, 1869: 484. -Painter \& Painter, 1974: 113. - Evenhuis, 1983: 466.

Villa brachialis; Hull, 1973: 372.

Lepidanthrax brachialis; Painter \& Painter, 1974: 113-116. - Painter et al., 1978: 34. -Evenhuis, 1983: 466. (new synonym).

Anthrax quinquepunctatus Thomson, 1869: 484. - Evenhuis, 1983: 486.

Villa quinquepunctata; Hull, 1973: 373.

Lepidanthrax quinquepunctata; Painter \& Painter, 1974: 113

Lepidanthrax quinquepunctatus; Painter \& Painter, 1962: 129; Painter et al., 1978: 36. - Evenhuis, 1983: 486. (new synonym).

Holotype. Lepidanthrax tinctus (Fig. 1) Female: Kinb; Type; 286 / 60; Naturhistoriska / Riksmuseet / Stockholm.

Female. Body length: 8-8.5mm; wing length: $8-8.5 \mathrm{~mm}$.

Head: distance between eyes at vertex about three times the length of the ocellar tubercle; front and face covered with golden yellow scales and sparse black hairs; antennae widely separated at basis; two first articles about the same length and color, with long black hairs; third article bulb-shaped with terminal portion styliform elongated two times the length of the two first articles together, ending in a little apical style; proboscis long exceeding oral margin a little less than half of its length; palpus brown with dark brown hairs, and length about $1 / 3$ proboscis length; occiput with white scales; occiptal fringe white.

Thorax. Postalar callus with 4 long black bristles; dorsum with yellow scales; meron and metakatepisternum bare, metanepisternum with white scales on the lower portion, katatergite with long yellow hairs, anepimeron with long white hairs on the fore portion, katepisternum with long white hairs on the hind upper portion, anepisternum with long white hairs in all the surface. Legs: covered with yellow scales and black hairs; tibiae II and III with black bristles; femur II at anteroventral surface with 2-4 bristles on middle third, femur III at anteroventral surface with 3-4 sparsed black bristles on apical two thirds (some specimens with bristles only in apical third). Wing: (Fig.2) light brown with lighter areas in center of cells and beyond the posterior margin; $\mathrm{R}_{2}+3$ arises exactly above $\mathrm{r}-\mathrm{m}$ crossvein; first posterior cell open on wing margin at a distance a little shorter than the length of $r-m$ crossvein; anal cell open on wing margin at a distance about the length of the r-m crossvein.

Abdomen: dorsum covered with brown and yellow scales; first and second segments with long white hairs laterally, the others with brown and white scales, and long black bristles laterally; venter covered with white scales and sparse white hairs.

Male. Body length: $6.8-7.5 \mathrm{~mm}$; wing length: $6.8-7.5 \mathrm{~mm}$; head: distance between eyes at vertex, about two times the length of the ocellar tubercle; Wing: (Fig.3) hyaline with a brown area at base, all the costal cell, posterior half of the 
first submarginal cell, and marginal cell from the origin of $\mathrm{R}_{2+3}$ till apex, with an hyaline portion in center of this area; brown areas bordering all crossveins and the contact of the third posterior cell/discal cell/ $\mathrm{Cu}_{1}$.

Discussion. The color pattern of the wing used as a diagnostic character to segregate $L$. brachialis from $L$. tinctus is an evident sexual dimorphism character, since in $L$. brachialis only the males were known and in L. tinctus only the females. In L. quinquepunctatus where both sexes were known, the male has the same color pattern of the wing of L. brachialis, and the female, the same of L. tinctus. As other morphological characters do not vary, there is no reason to treat them as different taxa. Different color patterns for male and female wing, were already reported for other species of this genus (HALL 1976).

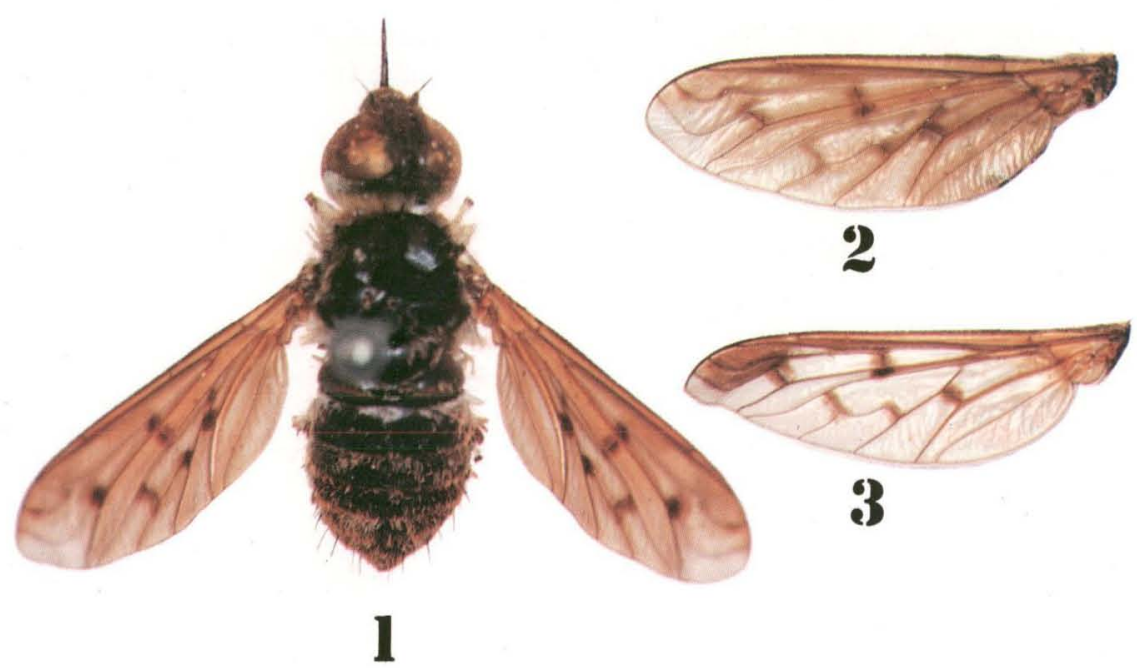

Fig. 1-3 (1) Holotype of Lepidanthrax tinctus; (2) wing of the female; (3) wing of the male.

ACKNOWLEDGMENTS. We are very grateful to Dr. Bert Viklund (Naturhistoriska Riksmuseet, Swedish Museum of Natural History), for the loan of the type material and also to Dr. Sérgio Augusto Fragoso (EMBRAPA) for the photos.

\section{REFERENCES}

EvenHuis, N.L. 1983. An indexed bibliography of Bombyliidae (Insecta, Diptera), vol.4. In: Theses Zoologicae. Braunschweig, J. Cramer, 493p.

HaLl, J.C. 1976. A revision of the North and Central American species of Lepidanthrax Osten Sacken (Diptera: Bombyliidae). Trans. Amer. Entomol. Soc. 102: 289-371.

HuLL, F.M. 1973. The beeflies of the world. The genera of the family Bombyliidae.

Bull. U.S. Nat. Mus. 286: 3-687. 
Osten SACKEn, C.R. 1886. Diptera, vol. I (part), p.1-24, 25-48, 49-72, 73-104, 105-128. In: F.D. GODMAN \& O. SALVIN (Eds). Biologia Centrali-Americana, Zoologia-Insecta-Diptera 1. London, 378p.

PAINTER, R.H. \& E.M. PAINTER. 1962. Notes on and redescriptions of types of North American Bombyliidae (Diptera) in European museums. Jour. Kansas Ent. Soc. 35: 2-164.

1974. Notes on and redescriptions of types of South American Bombyliidae (Diptera) in European and United States Museums. Res. Publ. Kansas State Univ. Expt. Sta. 168: 1-322.

PAinTER, R.H.; E.M. PAINTER \& J. HALl. 1978. 38. Family Bombyliidae, p.1-92. In: N. Papavero (Ed.). A Catalogue of the Diptera of the Americas South of the United States. São Paulo, Museu de Zoologia, Universidade de São Paulo.

Thomson, C.G. 1869. 6. Diptera. Species nova descripsit, p.443-614. In: K.S. VETENSKAPS-AKADEMIEN (Ed.). Kongliga svenska fregatten Eugenies resa omkring jorden 2. Stockholm, 617p, [1868].

Recebido em 25.IX.1995; aceito em 02.XII.1996. 